\title{
CLUSTER WITH FLO-STAR MAX CLAW WITH CROSSING MILK CONNECTION PIPES
}

\author{
Adam Luberański*, Marian Wiercioch, Józef Szlachta, Aleksander Krzyś, Danuta Skalska \\ Institute of Agricultural Engineering, Wroclaw University of Environmental and Life Sciences \\ *Corresponding author: e-mail: adam.luberanski@up.wroc.pl
}

\begin{tabular}{|c|c|}
\hline ARTICLE INFO & ABSTRACT \\
\hline $\begin{array}{l}\text { Article history: } \\
\text { Received: January } 2016 \\
\text { Received in the revised form: } \\
\text { February } 2016 \\
\text { Accepted: April } 2016\end{array}$ & $\begin{array}{l}\text { Improvement of mechanical milking in the aspect of cow's udder } \\
\text { health and maintaining correct milking parameters is possible through } \\
\text { e.g. constant improvement of the structure of clusters. A cluster with } \\
\text { a specific claw with crossing milk connection pipes Flo-Star Max with } \\
\text { liners with a round profile of the barrel of DK1X. The objective of the }\end{array}$ \\
\hline $\begin{array}{l}\text { Key words: } \\
\text { machine milking, } \\
\text { cluster, } \\
\text { milking parameters }\end{array}$ & $\begin{array}{l}\text { paper was to analyse usefulness of this type of the structure of the } \\
\text { machine for mechanical milking of cows. Measurements of simulated } \\
\text { milking were carried out in a laboratory to the upper milking pipeline } \\
\text { at variable mass intensity of liquid flow within } 0-8 \mathrm{~kg} \cdot \mathrm{min}^{-1} \text {, for four } \\
\text { penetrations of artificial teats of } 100,75,62,50 \mathrm{~mm} \text { at the systemic } \\
\text { negative pressure values within } 50 \text { to } 44 \mathrm{kPa} \text {, simultaneous and alter- } \\
\text { nating pulsation and during real milking of cows in a cowshed. Using } \\
\text { a multivariate analysis of variance, the impact of independent varia- } \\
\text { bles of an experiment on the values of average vacuum of suction, } \\
\text { vacuum fluctuations in cycle, average drop of vacuum in a cycle were } \\
\text { proved. Analysis of the machine operation in a milking parallel par- } \\
\text { lour in real mechanical milking conditions and difficulties in placing } \\
\text { a machine on the cow's udder as well as violent milk flow were } \\
\text { reported and the milk flow of } 3.5 \mathrm{~kg} \cdot \mathrm{min}^{-1} \text { was exceeded with its } \\
\text { characteristic balancing in the rhythm of a pulsator. }\end{array}$ \\
\hline
\end{tabular}

\section{Introduction}

Numerous varied factors influence high quality raw milk production. Milking hygiene is the most important one. Unfavourable hygienic conditions during milking influence less or more intensive microbiological contamination of milk during milking and initial processing. Even careful compliance with milking hygiene rules does not guarantee obtaining milk free of any microorganism (Kupczyk et al., 2003). In all herds of dairy milk, pathogens are transmitted and as a rule there is no possibility of their complete destruction (Philpot and Nickerson, 2006). Correct operation and the structure of milking devices constitute the second important factor. Cows milked with mechanical milking machines are exposed to health problems related mainly to destructive operation of vacuum on teat tissues, presence of vacuum fluctuations in the milking machine installation and the so-called reverse flows between a claw and a teat chamber of a teatcup (Balbierz, 2009). A considerable progress in mechanical milking may be achieved by constant modernization of milking 
machines towards improvement as well as full automation of milking processes (Luberański et al., 2015). IQ cluster, where a claw with four separate milk chambers (each with $50 \mathrm{~cm}^{3}$ volume) equipped with ball valves was used, are an example of a new thought in the development of milking machines. Solution of this type assumes elimination of a cross reverse flow of milk between udder quarters and limitation of infection of healthy quarters with milk coming from infected quarters (Luberański et al., 2013; Luberański et al., 2015). The research which was carried out in a laboratory proved that despite a lower total volume of a claw of IQ cluster the analysed pressure parameters of milking were comparable to a classical clusters (Luberański et al.,2013). Other suggested solutions are the so-called clusters which aim at reduction of empty milking by individual control of parameters of milking cups operation in relation to the speed of milk flow from teats (Jędruś 2011; Jędruś 2013a; Jędruś 2013b). Milpro P4-C a milking system with Dynamic P4C cluster is an exemplary system which carried out such milking. This device controls the frequency (each teat) and the pulsation coefficient through a built-in deflector in a claw of the machine in relation to the intensity of milk outflow. After the milk had flown through any quarter a liner in a milking cup is closed. However, cyclically in a specific time it is opened as to the end of milking (Luberański et al., 2015).

\section{Objective of paper}

A cluster with Flo-Star Max with non-typical crossing connection pipes is a new structure among modern machines on the market of milking techniques. The objective of the paper was to analyse a usefulness of this type of a solution for milking cows based on the simulated and real mechanical milking of cows in a cowshed.

\section{Methodology of research}

A cluster (fig. 1a) with Flo-Star Max claw with crossing milk pipelines and teat gums DK1X with the round profile of the stem part (Fig. 1b) without air supply to a milking unit is the object of the research which basically differs from the structure of classical solutions of claws. The machine is designed for operation in milking parlours in the system of reverse pulsation (front, back), weight $1.6 \mathrm{~kg}$ and the volume of a milking chamber of a claw is $340 \mathrm{~cm}^{3}$. Milk connection pipes placed in a claw at the angle of approx. $45^{\circ}$ are designed to prevent violent and cross reverse flow of milk between udder quarters as well as to limit regular and irregular fluctuations of vacuum. The research was carried out in a milking laboratory of the Institute of Agricultural Engineering in Wroclaw under conditions of simulated milking on the measurement stand built based on the installation of a milking pipeline machine (fig. 2) and in the dairy cowshed of RZD farm in Swojec. In laboratory conditions of the research on vacuum changes within the cluster and observation of the nature of milk replacing liquid flow was carried out in various measurement variants. 

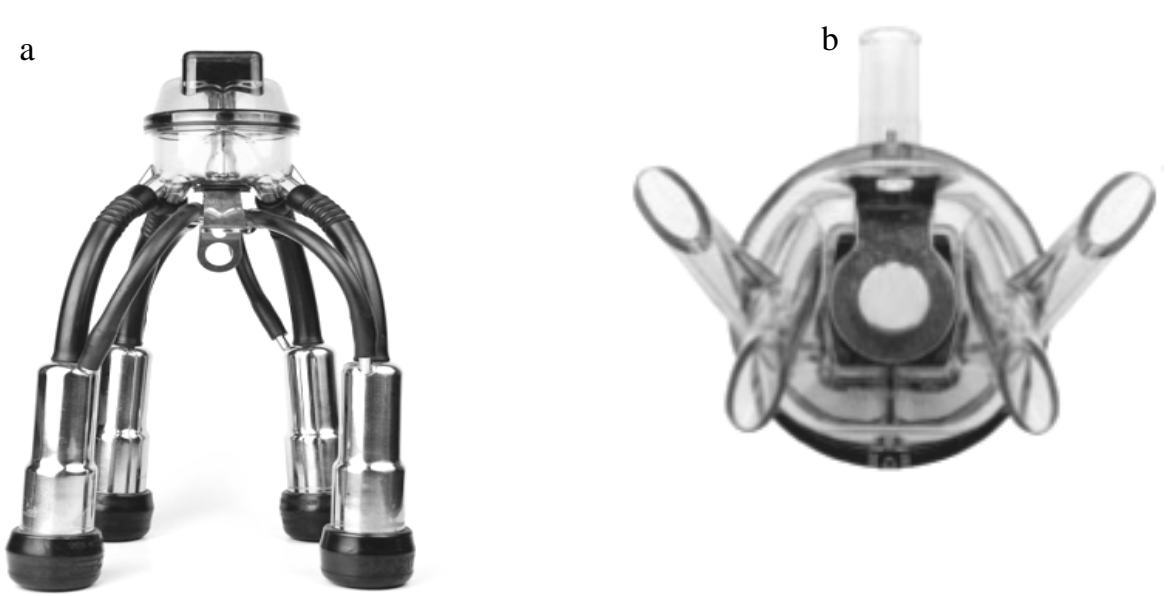

Figure 1. $a$-Cluster with a claw Flo-Star Max; $b$ - Image of dairy milk connection pipes in a claw

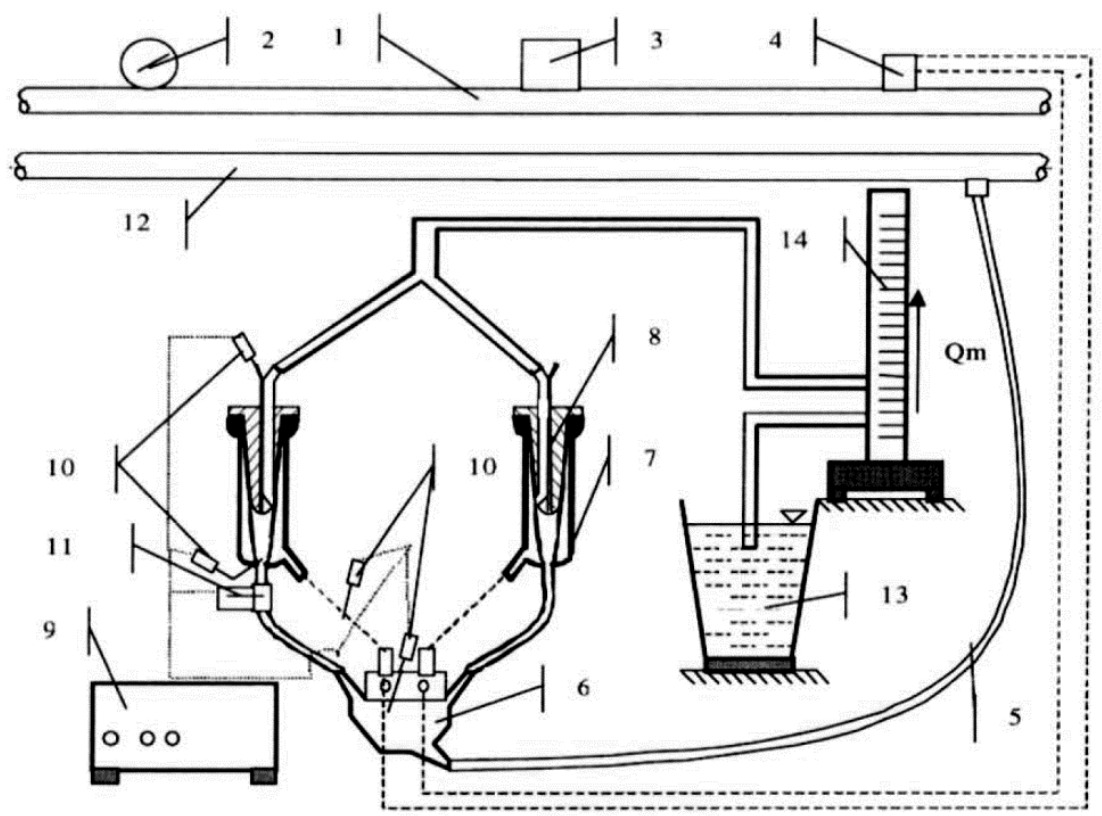

Figure 2. Schematic representation of the measurement stand: 1 - air pipeline, 2 - vacuum gauge, 3 - vacuum regulator, 4 - pulsator, 5- long milk tube, 6 - claw, 7 - teatcup, 8 - artificial teat, 9 - recorder, 10 - vacuum sensors, 12 - milking pipeline, 13 - tank with milk replacing liquid, 14 - rotameter with the flow regulator 
Alternating pulsation (a pulsator with pneumatic dumbing with a pulsator ratio $60 \%$ and pulsation 60/40, pulsation rate 60 pulses $\cdot \mathrm{min}^{-1}$ ) and simultaneous pulsation (electronic pulsator with parameters corresponding to a pulsator to alternative pulsation) controlled with working negative pressure with the values of 50,48, 46, $44 \mathrm{kPa}$ at the stream of mass of the flowing milk replacing liquid within 0 to $8 \mathrm{~kg} \cdot \mathrm{min}^{-1}$, every $2 \mathrm{~kg} \cdot \mathrm{min}^{-1}$ with the use of a rotameter (Kÿtöla) for the length of artificial teats with the structure compliant to the standard ISO 6690 (2007) 100, 75, 62, $50 \mathrm{~mm}$. Vacuum in the air pipeline and milk pipeline ( $\varnothing 50 \mathrm{~mm}$, length of $15 \mathrm{~m}$ ) was produced by a vacuum pump with the efficiency of 51 $\mathrm{m}^{3} \cdot \mathrm{h}^{-1}$ (Westfalia) and maintained at the stable level by vacuum regulator Vacurex 5000 . The milking machine was connected to a milk pipeline (suspension height of $1.9 \mathrm{~m}$ ) with a stand tap Combi Standard type with a long milk tube with $18 \mathrm{~mm}$ diameter and $1.9 \mathrm{~m}$ length. Measurements of vacuum in a milk chamber of a claw, short pulse tube, teat chamber and on the top of a teat were carried out with a current vacuum sensors SML (ADCEltek) class $0.25 \%$ (measuring scope 0-60 kPa). Signals from sensors were recorded by a recorder composing a four-module base NIcDAQ 9174 equipped with two current modules NIcDAQ 9203 and one voltage NIcDAQ 9237. The measured signals were recorded with $400 \mathrm{~Hz}$ frequency directly on the computer disc pursuant to a configuration defined in "Symulacja" application (application designed for determination of milking parameters). Then, the registered data were subjected to further processing in Excel program.

In the second stage of research on the dairy cows farm in RZD Swojec in Wroclaw, we mainly focused on practical utility aspects of the investigated apparatus i.e. placing and maintaining the machine on udders and milk flow in a claw at varied speeds of milk - out. The observation was carried out on the stand no. 1 in a two-row milking parlour $4 \times 4$ parallel milking type equipped with the system of herd management - Alpro with a milk flow control meter MM27BC. Moreover, the stand was equipped with an electronic pulsator EP 2090 for alternative milking with the coefficient of the pulsator ratio $60 \%$ and pulsation of $60 / 40$ and pulsation rate 60 pulses $\mathrm{min}^{-1}$ with an autonomous system of taking off a cluster after milking. Milking of eight cows with the investigated machine without any previous selection was observed on the stand.

\section{Research results}

Conclusions concerning the obtained research results are usually carried out based on statistical application and courses of relations between dependent and independent variables of an experiment. Statgraphics 6.0 application was applied for statistical analysis of research results in the research. The multivariate analysis of variance which was carried out (tab.1) for the selected pressure parameters of the investigated milking machine proves clearly that two indpendent variables of an experiment i.e. the pulsation type and milk replacing liquid mass intensity influence all considered pressure parameters of milking at the level of significance $\alpha=0.00$. Statistically significant differences in case of the remaining variables, namely working vacuum and teat penetration were reported respectively for pss and dpsr and pss also at the level of $\alpha=0.00$.

Average negative pressure of suction pss defines conditions of milking of a cluster in the aspect of maintaining teats in the protruding position maintaining thus patency of a teat channel and a correct outflow of milk in the suction phase. (Luberański et al., 2013). 
Milking machine...

Table 1.

Results of multivariate analysis of variance of the impact of independent variables of an experiment on the vacuum fluctuations in cycle dp, average suction vacuum pss, average drop of vacuum in cycle dpsr for the cluster with Flo-Star Max claw and DK1X liners

\begin{tabular}{|c|c|c|c|c|c|}
\hline Parameter & $\begin{array}{c}\text { Source } \\
\text { of variability }\end{array}$ & $\begin{array}{l}\text { Pulsation } \\
\text { type } \\
\mathrm{Pu}\end{array}$ & $\begin{array}{c}\text { Working } \\
\text { vacuum } \\
P\end{array}$ & $\begin{array}{c}\text { Mass } \\
\text { liquid } \\
\text { flow intensity } \\
Q m\end{array}$ & $\begin{array}{c}\text { Teat } \\
\text { penetration } \\
\text { Pe }\end{array}$ \\
\hline \multirow{3}{*}{$\begin{array}{l}\text { Vacuum fluctuations } \\
\text { in cycle } d p\end{array}$} & $\begin{array}{c}\text { Number of free- } \\
\text { dom degrees }\end{array}$ & 1 & 3 & 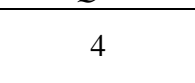 & 3 \\
\hline & $\begin{array}{l}\text { Level of signifi- } \\
\quad \text { cance } \alpha\end{array}$ & 0.00 & 0.97 & 0.00 & 0.00 \\
\hline & F test value & 146.148 & 0.079 & 78.80 & 44.66 \\
\hline \multirow{2}{*}{$\begin{array}{l}\text { Average vacuum of } \\
\text { suction pss }\end{array}$} & $\begin{array}{l}\text { Level of signifi- } \\
\quad \text { cance } \alpha\end{array}$ & 0.00 & 0.00 & 0.00 & 0.00 \\
\hline & F test value & 105.197 & 681.02 & 2327.57 & 26.56 \\
\hline \multirow{2}{*}{$\begin{array}{l}\text { Average drop } \\
\text { of vacuum in cycle } \\
d p s r\end{array}$} & $\begin{array}{l}\text { Level of signifi- } \\
\quad \text { cance } \alpha\end{array}$ & 0.00 & 0.00 & 0.00 & 0.07 \\
\hline & F test value & 97.599 & 2.322 & 10516.66 & 0.576 \\
\hline
\end{tabular}

Shaping of the value of average vacuum of suction (fig. 3) has a dropping trend along with the increase of mass stream of the liquid flowing through the machine. Decisively Qm is an independent variable, the so-called prevailing in the research on account of the biggest decrease of value not only of pss but also the remaining considered parameters in the entire scope of flows for all configurations of the cluster. Qm change with regard to flows 0-8 $\mathrm{kg} \cdot \mathrm{min}^{-1}$ causes a decrease of average vacuum of suction for both types of the used pulsation and working vacuum within 37 to $32.7 \mathrm{kPa}$ with a trend of a clear impact of teat penetration, especially, in the option with simultaneous pulsation - the shorter the teat used in the measurement the higher are pss values. This is a trend convergent with Grzybek's observations (2007) who investigating possibilities of milking with clusters at the reduced working vacuum in a herringbone parlour obtained similar relations between variables. One may state, taking into consideration the obtained research results, that the pss values recorded within the cluster are high enough, in particular at a border liquid flow of $\mathrm{Qm}=8 \mathrm{~kg} \cdot \mathrm{min}^{-1}$ that correct real mechanical milking with this cluster is possible. 
A. Luberański, M. Wiercioch, J. Szlachta, A. Krzyś, D. Skalska
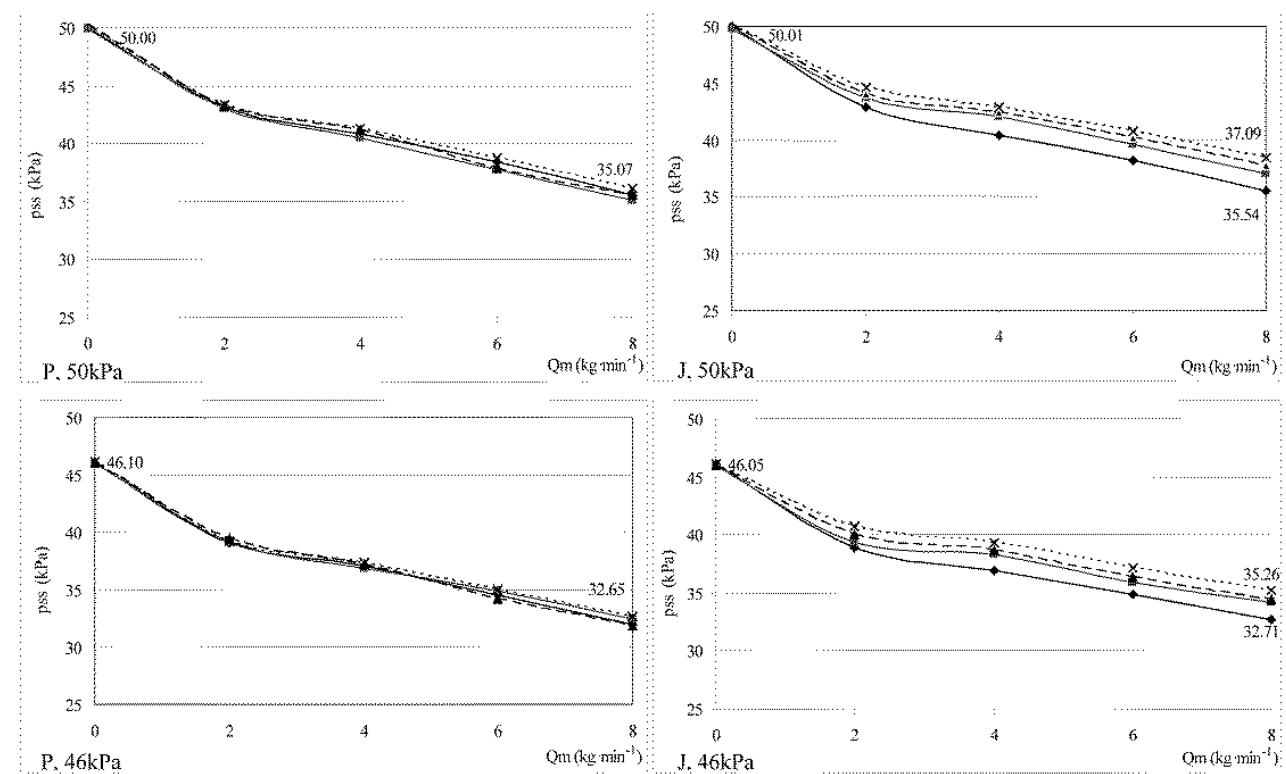

P. $46 \mathrm{kPa}$

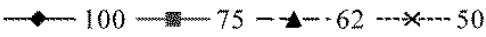

Figure3. Exemplary courses of average vacuum of suction pss in a function of stream of mass of milk replacing liquid $Q m$ of the cluster with Flo-Star Max claw and DK1X liners at vacuum of 50 and $46 \mathrm{kPa}$, teat penetration 100, 75, 62, $50 \mathrm{~mm}$, alternative pulsation $P$ and simultaneous pulsation $J$

Vacuum fluctuations in cycle dp are another important pressure parameter of milking. In the literature, this parameter is presented as a crucial factor which affects the milking course and udder health. For detailed analysis of dp values which may be generated in the cluster with the Flo-Star Max claw in the assumed measuring conditions, the values of the considered parameter were set in figure 4 as well as a function of intensity of liquid flow mass. Of course, courses of dp curves on the analysed diagrams are typical for clusters i.e. the higher is the liquid outflow and teat penetration both at the alternating and simultaneous pulsation, the higher are vacuum fluctuations. However, the issue of the value of the considered parameter has not been yet discussed. In case of alternative pulsation the investigated machine does not generate high vacuum fluctuations. Peak values of dp get to maximally approx. $8 \mathrm{kPa}$ for the shortest teats applied in the experiment with the length of $50 \mathrm{~mm}$. The change into two times longer teats proportionally reduces the dp level by approx. 50\%. So favourable relations are not observed when curves with simultaneous pulsation are analysed in figures. Simultaneous opening and closing of liners in the set of long teats $(100 \mathrm{~mm})$ raises the dp value in comparison to the alternative pulsation, not much because only by approx. $2 \mathrm{kPa}$. A considerable increase of vacuum fluctuations in cycle takes place along with the change of penetration of teats into shorter within the length of 75 to $50 \mathrm{~mm}$ oscillating at the fourfold level achieving as much as $20 \mathrm{kPa}$. In the light of the research con- 
Milking machine...

cerning of vacuum fluctuations (Luberański et al., 2006; Luberański et al., 2011; Luberański et al., 2013) it should be emphasised that the configuration of the investigated machine with Flo-Star Max claw gives greater possibilities of dp reduction.
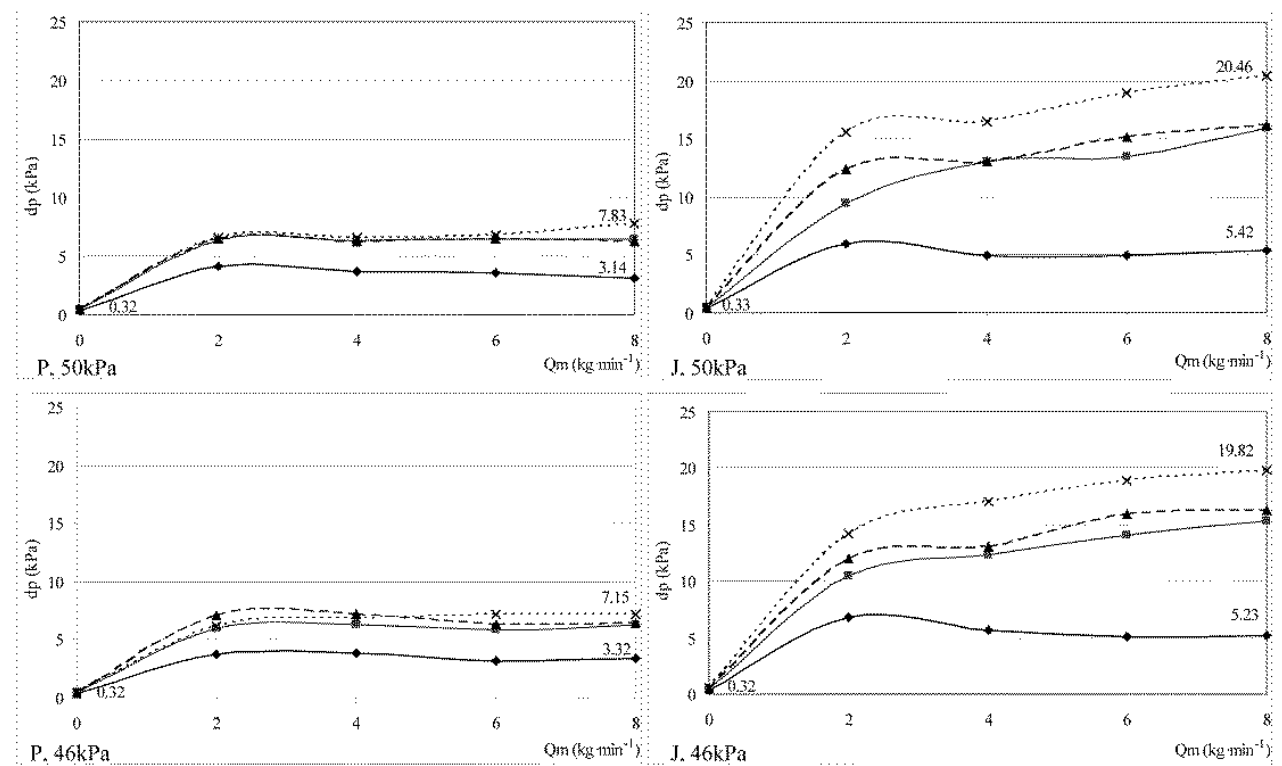

$$
\longrightarrow-100-75-\mathbf{A}-62-62-\cdots \cdots-50
$$

Figure 4. Exemplary courses of vacuum fluctuations in cycle dp in of courses as a function of the stream of milk replacing liquid Qm for the cluster with a claw Flo-Star Max and DK1X liners at vacuum of 50 and $46 \mathrm{kPa}$, teat penetrations of 100, 75, 62, $50 \mathrm{~mm}$, alternative pulsation $P$ and simultaneous one $J$

Empirical research prove that correct and safe milking with a cluster without the risk of sliding the cluster off teats is possible only when the average drop of vacuum in cycle dpsr within the cluster is lower than $20 \mathrm{kPa}$. Analysis of the relation between particular sources of variability and the considered parameter may lead to the statement that dpsr values have a greatly rising trend along with the increasing intensity of Qm liquid mass stream, and slight for the pulsation type and variables of working vacuum values. For typical speed of milk-out by cows within 2 and $4 \mathrm{~kg} \cdot \mathrm{min}^{-1}$ one may expect average drop of vacuum within $10 \mathrm{kPa}$ both for the teats penetration and pulsation type applied in the research. The obtained results of dpsr for the applied flows exceeding $4 \mathrm{~kg} \cdot \mathrm{min}^{-1}$ change linearly and achieve the maximum values at the level of $15.9 \mathrm{kPa}$ at $\mathrm{Qm}=8 \mathrm{~kg} \cdot \mathrm{min}^{-1}$, simultaneous pulsation and working vacuum of $50 \mathrm{kPa}$. In the remaining measuring variants, in the same conditions of the flowing mass stream of liquid, reduction of vacuum shape at the level of approx. $15 \mathrm{kPa}$ with a more advantageous trend of their limitation at the alternative pulsation and reduced working vacuum. 

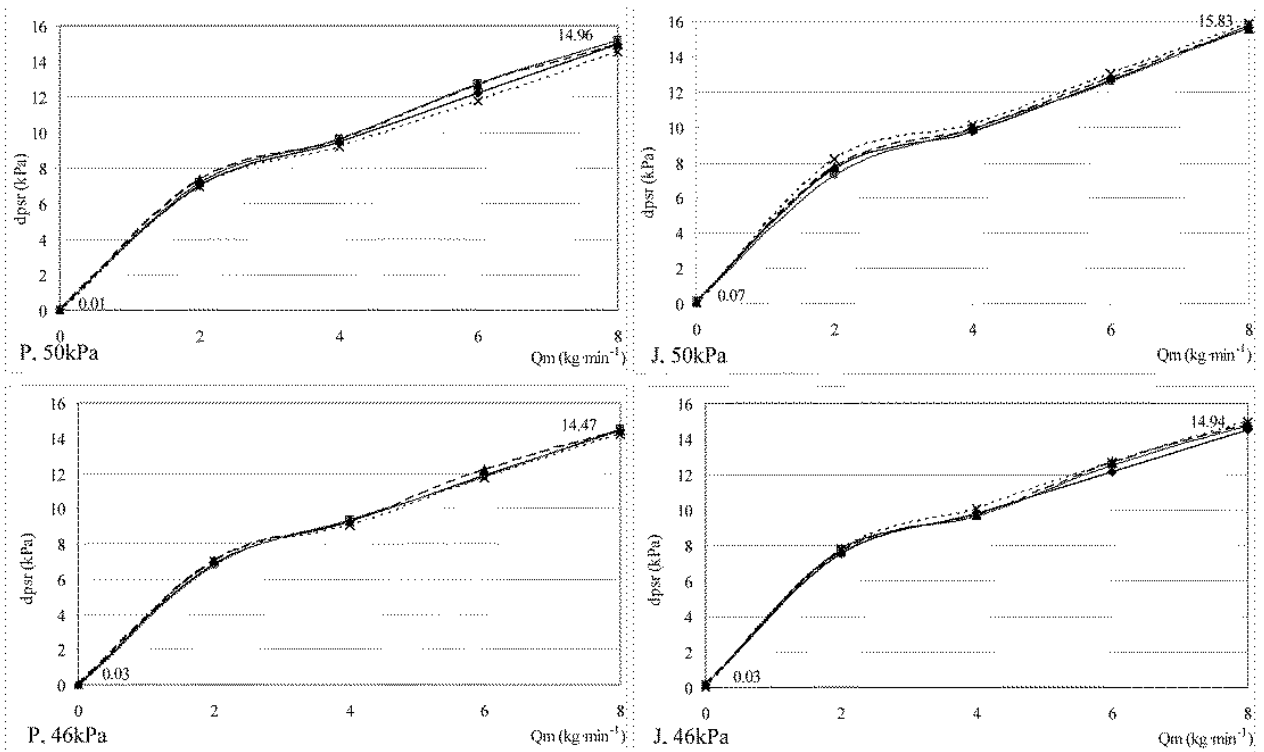

P. 46kPa

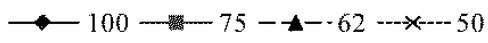

Figure 5. Exemplary courses of average drop of vacuum in cycle dpsr as a function of the stream of milk replacing liquid Qm for the cluster with a claw Flo- Star Max and DK1X liners at vacuum of 50 and $46 \mathrm{kPa}$, teat penetrations of 100, 75, 62, $50 \mathrm{~mm}$, alternative pulsation $P$ and simultaneous one $J$

The second stage of research was carried out in a cowshed of RZD farm Swojec in Wroclaw where cows were milked by a milkmaid (a woman with 15 years of experience) who correctly carried out all pre and post milking activities. Milking was carried out in a parallel parlour on the stand no. 1 investigated with a cluster and on the remaining stands with Hormony clusters. In this type of parlours, cows stand perpendicularly to the channel of a milkmaid. As a result cluster is placed from the back between the back limbs of an animal. This operation is uncomfortable thus it requires dexterity and experience. Placing a unit with Flo-Star Max claw is more difficult and more complex with comparison to Harmony unit. Difficulty results from the cross location of milk connection pipes in a claw (fig. 1b) i.e. connection pipes from the front part of a claw are directed backwards and the back ones- frontwards. Such a system disables complete bending of short milk pipelines of teatcups on connection pipes of a claw. As a result the unit sucks great amount of atmospheric air causing difficulties in placing teatcups on the most distant front teats. Fast placing of the unit by a milkmaid required keeping teatcups in place and directing them and back teats towards front teats. When the unit is placed on an udder, the initial stage of milking to the moment when the milk flow of $3 \mathrm{~kg} \cdot \mathrm{min}^{-1}$ is obtained, was peaceful. A mild milk flow on the walls of a claw and its fast release were observed. Milk movement when the flow speed of $3.5 \mathrm{~kg} \cdot \mathrm{min}^{-1}$ was obtained was completely different. In a claw, a violent front 
overlapping of milk streams flowing out milk connection pipes took place. As a result filling of a claw with milk in approx. $40 \%$ with its characteristic balancing in the rhythm of pulsator's operation took place. This phenomenon may negatively affect physical and chemical properties of raw milk and in particular of initial lipolysis. No problems with staying of the investigated cluster on udders were reported during the entire mechanical milking process.

\section{Conclusions}

1. Multivariate analysis of variance for the selected pressure parameters of milking pss, dp, dpsr of the investigated milking machine with DK1X liners and a Flo-Star Max claw proved clearly that two independent variables of the experiment i.e. a pulsation type and mass intensity of flow of milk replacing liquid affect all considered pressure milking parameters on the level of significance of $\alpha=0.00$. Statistically significant differences in case of the remaining variables, namely working pressure and teat penetration were reported respectively for pss and dpsr and pss also at the level of $\alpha=0.00$.

2. Taking into consideration the obtained results of laboratory research it should be stated that the value of pss, dp and dpsr parameters registered within the cluster are favourable in the entirely used scope of flows of milk replacing liquid $\left(\mathrm{Qm}=0-8 \mathrm{~kg} \cdot \mathrm{min}^{-1}\right)$ which enables correct and safe operation of real mechanical milking with this unit in particular with alternative pulsation.

3. Placing the investigated unit from the back between the back limbs of an animal on udders in a parallel parlour was difficult because of the structure of the claw, i.e. connection pipes from the front part of a claw are directed backwards and the front ones frontwards. Such a solution disabled complete bending of short milk pipelines of milking cups on connection pipes of a claw. As a result the unit sucks great amount of atmospheric air causing difficulties in placing cups on the most distant front teats.

4. It was noticed that when the speed of milk-out exceeded $3.5 \mathrm{~kg} \cdot \mathrm{min}^{-1}$, an unfavourable phenomenon took place i.e. violent, front overlapping of milk streams flowing out connection pipes in a claw. As a result a claw was filled in with milk in approx. $40 \%$ with its characteristic balancing in the rhythm of the pulsator operation. Thus, there is a possibility of changes of physical and chemical properties of the obtained milk. No problems with staying of the investigated unit on cow udders were reported during the tests.

\section{References}

Balbierz, K. (2009). Parametry pracy aparatów udojowych z gumami strzykowymi okragłymi i kwadratowymi oraz ich wpływ na proces doju. Praca magisterska. UP Wrocław. Maszynopis.

Grzybek, M. (2007). Parametry pracy wybranych aparatów udojowych przy obniżonym podciśnieniu systemowym $w$ dojarni typu ,rybia ość”. Praca magisterska, maszynopis, UP we Wrocławiu, 75.

Jędruś, A. (2011). Ocena zastosowania nowej konstrukcji dojarki czteroćwiartkowej do określania wybranych parametrów zdolności wydojowej krów. Agricultural Engineering, 9(134), 81-86.

Jędruś, A. (2013a). Zapobieganie pustodojom. Hodowla i chów bydła, 1, 34-38.

Jędruś, A. (2013b). ABC doju ćwiartkowego. Hodowla i chów bydta, 2, 32-36.

Kupczyk, A.; Mastyj, A.; Daniel, Z.; Gaworski, M. (2003). Dojarka Mechaniczna. Energopol-Trade Poligrafia Sp. z o. o., ISBN 83-917877-0-2, 194. 
Luberański, A.; Pawlak, T.; Szlachta, J. (2006). Stabilność podciśnienia w aparatach udojowych działających przemiennie i jednocześnie w różnych systemach doju. Agricultural Engineering, 3, 247-254.

Luberański, A.; Wiercioch, M.; Szlachta, J. (2015). Nowoczesne rozwiąania urządzeń do doju krów. XXIII Szkoła Zimowa Hodowców Bydła „Współczesne problemy w produkcji mleka i Wołowiny”. Materiały konferencyjne, Zakopane, 92-99.

Luberański, A.; Wiercioch, M.; Krzyś, A.; Skalska, D. (2013). Stabilność podciśnienia w aparatach udojowych IQ i Classic 300 podczas symulowanego doju mechanicznego. Agricultural Engineering, 4(147), 203 - 212.

Luberański, A.; Wiercioch, M.; Krzyś, A.; Szlachta, J. (2011). Wahania podciśnienia w aparatach udojowych przy obniżonym podciśnieniu systemowym w dojarni typu „rybia ość”. Agricultural Engineering, 8(133), 189-196.

Philpot, N.; Nickerson, S. (2006). Zwyciężyć w walce z mastitis. WestwaliaSurge Polska Sp. zo.o., Bydgoszcz, 191, ISBN 978-83-923637-0-5.

ISO - 6690:(2007). Milking machine installations - Mechanical tests.

\section{APARAT UDOJOWY Z KOLEKTOREM FLO - STAR MAX Z KRZYŻOWYM ULOŻENIEM KRÓĆCÓW MLECZNYCH}

Streszczenie. Poprawa procesu mechanicznego doju w aspekcie zdrowotności krowiego wymienia oraz utrzymania prawidłowych parametrów doju jest możliwa poprzez np. stałą poprawę konstrukcji aparatów udojowych. Jedną $\mathrm{z}$ takich konstrukcji jest aparat udojowy o specyficznym kolektorze z krzyżowo ułożonymi króćcami mlecznymi o nazwie Flo-Star Max wraz z gumami strzykowymi o okrągłym profilu części trzonowej DK1X. Celem badań była, analiza przydatności tego typu konstrukcji aparatu do mechanicznego doju krów. Pomiary symulowanego doju przeprowadzono w laboratorium do górnego rurociągu mlecznego, przy zmiennych masowych natężeniach przepływu cieczy w zakresie $0-8 \mathrm{~kg} \cdot \mathrm{min}^{-1}$, dla czterech penetracji sztucznych strzyków 100, 75, 62, $50 \mathrm{~mm}$, przy wartościach podciśnień systemowych w zakresie od 50 do $44 \mathrm{kPa}$, pulsacji jednoczesnej i przemiennej oraz podczas rzeczywistego doju krów w oborze. Stosując wieloczynnikową analizę wariancji wykazano wpływ zmiennych niezależnych doświadczenia na wartości średniego podciśnienia ssania, wahań podciśnienia, średniego spadku podciśnienia w cyklu. Przeprowadzono analize pracy aparatu w dojarni typu „bok w bok” w warunkach rzeczywistego doju mechanicznego i stwierdzono trudności w zakładaniu aparatu na krowie wymiona oraz burzliwy przepływ mleka po przekroczeniu przepływu mleka $3,5 \mathrm{~kg} \cdot \mathrm{min}^{-1}$, z charakterystycznym jego balansowaniem w rytm pulsatora.

Słowa kluczowe: dój mechaniczny, aparat udojowy, parametry doju 